\title{
A Study for Occupational Aspiration of Senior Secondary Students Belonging To Business Class \& Service Class Parents
}

\author{
${ }^{1}$ Archana Singh, ${ }^{2}$ Dr. Madhu Sharma \\ ${ }^{1}$ Research Scholar-Pacific University Udaipur, Rajasthan, India \\ ${ }^{2}$ Sr. Lecturers-Education NTTC (MLSU), Udaipur, Rajasthan, India
}

\begin{abstract}
The educational and vocational decisions at adolescent stage pave the way for future decisions to be taken by any individual in the world of work. Selection of career and setting in it is an important task and a source of personal gratification. In present time science and technology, thousands of occupations have been thrown open to an individual. The choice of right occupation is becoming difficult as our entire society grows more complex, more specialized and more technological oriented. The present study tries to tap the occupational aspiration of senior secondary students belonging to business class and service class parents. The objective of the study is to measure there is any significant difference between occupational aspiration of senior secondary students belonging to business class and service class parents with respect to selection of best suitable occupation post school. For the present study investigator has taken survey method and purposively selected 160 students, 80 students from government school and 80 from private schools of Udaipur (Rajasthan, India) district. For further investigation researcher taken standardized tool of occupational aspiration prepared by Dr. J. S.Gerwal and administer on students. To analysed data by using Mean, S.D. and T-test. The result of study shows that occupational aspiration of students belonging to business class parents are better than students belonging to service class parents.
\end{abstract}

Key Words: Occupational aspiration, Business class parents, Service class parents

\section{Introduction}

"Work occupying eight hours out of twenty four, five days out of seven, fifty weeks out of fifty two, fifty years out of seventy,

Occupies a prominent place in life of modern man"

The educational and vocational decisions at adolescent stage pave the way for future decisions to be taken by any individual in the world of work. Selection of career and setting in it is an important task and a source of personal gratification. In present time science and technology, thousands of occupations have been thrown open to an individual. The choice of right occupation is becoming difficult as our entire society grows more complex, more specialized and more technological oriented.

Occupational aspiration and academic achievement is also determined by parental background /socioeconomic status of parents like parents having their own business or working under terms of employment. Children belonging to Business class are those whose parents are having business of any sort while Children belonging to service class are those whose parents are working under certain terms of employment. An incorrect occupational choice is made either because parents have a fixed notion about a vocation or people of low ability aspire for a vocation not fit for them or those of high ability have to accept an occupation because of diverse and unfavourable conditions.

As parental background influences the behaviour of child, Performance and occupational choice, hence the present study is an Attempt to know Occupational aspiration of Children belonging to business class parents and Children belonging to service class parents at senior secondary level.

Statement of the Problem:

"A Comparative Study of Occupational Aspiration \& Academic Achievement of Senior Secondary Student Belonging to Business Class \& Service Class Parents"

Define terms:

$>$ Occupational Aspiration: occupational aspiration is one's desire for any occupation or profession. One's preference, liking, willingness, inclination to any particular occupation, job or profession is known as occupational aspiration.

"Ambitions of an Individual in occupational areas concerned with performance, prestige and status"

By - Haller and miller (1963) 
$>$ Children Belonging to Business Class: If a child's parent is engaged in some kind of business, they are treated to be the wards belonging to business class parents. In present study children belonging to business class are those students of senior secondary level whose parents is having business of any sort or is having profession of any sort.

$>$ Children Belonging to Service Class: If a child's parents are employed in government or private services. Such a student is treated to be belonging to service class.

\section{Objectives of Study:}

$>$ To find out occupational aspiration of senior secondary students with respect to selection of best suitable occupation post schooling.

$>$ A comparative study of occupational aspiration of senior secondary students belonging to business \&service class parents with respect to selection of best suitable occupation post schooling.

\section{Hypothesis:}

There is no significant difference between occupational aspiration of senior secondary student belonging to service class \& business class parents.

\section{Research Design:}

Research design or techniques; refer to the methods which the researcher used in performing research operation. In other words all those method which are used by the researcher during the course of studying the research problem are termed as research method. Since the objective of research is to arrive at solution for a given problem the available data and the unknown aspects of the problem have to be related to each other to make a solution possible. Considering the nature of the study the researcher has selected Survey Method which is more appropriate method for the type of the study.

\section{Sample for the present study:}

For the present study researcher has used purposive sampling . The purposive sampling is selected by some arbitrary method because it is known to be representative of total population. The idea is to pick out the sample in relation to some criterion which is considered important for the particular study.

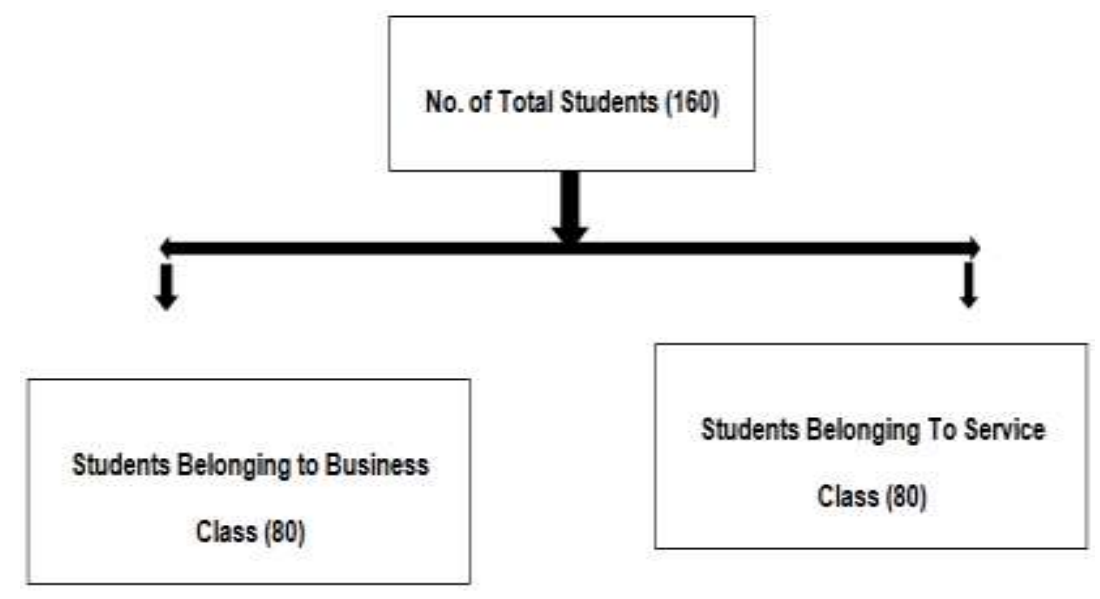

Research Tool: For any investigation the collation of adequate and reliable data are essential. To collect the data properly certain device are required. These devices are called tools. For present study following tool are use: - Standardized tool- "Occupational Aspiration Scale” prepared by Dr. J.S. Grewal (Rtd.) Professor of Education, Regional College of Education, Bhopal (Madhya Pradesh, India)

\section{Collection of Data:}

Occupational aspiration scale (standardized tool) administered on the selected sample of 160 senior secondary students and response given by them was considered as occupational aspiration data for present study. Statistics employed are mean, standard deviation and T-test.

\section{Result \& Discussion}

After collection of data were classified, summarized and analysed in scientific manner by using mean, S.D. and T-test. These measurements are presented in this table. 


\begin{tabular}{|c|c|c|c|c|c|c|c|}
\hline \multirow[b]{2}{*}{$\begin{array}{l}\text { Sl. } \\
\text { No. }\end{array}$} & \multirow[b]{2}{*}{ Occupation } & \multicolumn{2}{|l|}{ Mean } & \multicolumn{2}{|l|}{ SD } & \multirow[b]{2}{*}{ T-test } & \multirow[b]{2}{*}{ Significance on $0.05 \& 0.07$} \\
\hline & & $\begin{array}{l}\text { Business } \\
\text { Class }\end{array}$ & $\begin{array}{l}\text { Service } \\
\text { Class }\end{array}$ & $\begin{array}{l}\text { Business } \\
\text { Class }\end{array}$ & $\begin{array}{l}\text { Service } \\
\text { Class }\end{array}$ & & \\
\hline 1 & Lawyer & 1.53 & 1.33 & 3.52 & 2.77 & 3.11 & At 0.01 level of confidence \\
\hline 2 & Agricultural Inspector & 0.73 & 0.52 & 2.87 & 1.99 & 2.99 & At 0.01 level of confidence \\
\hline 3 & Doctor & 0.42 & 0.327 & 1.95 & 1.86 & 2.72 & At 0.01 level of confidence \\
\hline 4 & Primary School Teacher & 0.27 & 0.19 & 1.80 & 1.72 & 3.22 & At 0.01 level of confidence \\
\hline 5 & Foreign Services & 0.18 & 0.14 & 1.69 & 1.55 & 2.88 & At 0.01 level of confidence \\
\hline 6 & Barber & 0.11 & 0.099 & 1.41 & 1.43 & 3.25 & At 0.01 level of confidence \\
\hline 7 & Psychologist & 0.09 & 0.065 & 1.42 & 1.37 & 2.18 & At 0.05 level of confidence \\
\hline 8 & Motor Mechanic & 0.08 & 0.025 & 1.35 & 1.20 & 2.05 & At 0.05 level of confidence \\
\hline 9 & Hawkers & $\mathbf{0 . 0 3}$ & 0.02 & 1.25 & 1.15 & 3.63 & At 0.01 level of confidence \\
\hline 10 & Postman & 0.01 & 0.002 & 1.18 & 1.06 & 3.32 & At 0.01 level of confidence \\
\hline
\end{tabular}

At .01 level of confidence $=2.61$, At .05 level of confidence $=1.98$

The ' $\mathrm{T}$ ' value depicted on above table, that there is significance difference between occupational aspiration of senior secondary students belonging to business class and service class parents with respect to their occupation Lawyer, Agricultural Inspector, Doctor, Primary School Teacher, Foreign Services, Barber, Hawkers and Postman at 0.01 level of confidence and Psychologist \& Motor Mechanic at 0.05 level of confidence.

\section{Utility of Study:}

On the basis of above result of Occupational Aspiration, present study is helpful for students, teachers. Parents and researchers:

$>$ Students know very well which area is fruitful in their future life as a profession.

$>$ Parents' guide their children (Son/Daughter) in choosing occupation for future life on the basis of interest and ability.

> Teacher/Counsellor gives proper guidance to their students on choosing best suitable occupation.

\section{Conclusion}

The aim of this study is to find out occupational aspiration of senior secondary students belonging to business class \& service class Parents. The findings of the study throw a valuable light on certain facts which can be of great importance for teachers, parents, students and researchers. It is observed that occupational aspiration of students belonging to business class parents are better than students belonging to service class parents. The investigator wishes to conclude this report with the hope that the research study will be able to make its contribution towards making of suitable occupational choice by the adolescents according to their potentialities.

\section{References}

[1]. Borg W.R.: "Education Researches on Introduction", New York, Longman Green \& Co. Ltd.

[2]. C.V. Good: "The Methodology of Education Research" A Appleton centaury crofts", Inc. New York.

[3]. Cocher, W.G.: "Sampling Technique", Bombay, Publishing House.

[4]. Koul, Lokesh (1984) "Methodology of Educational Research" Vikas Publishing House Pvt. Ltd.

[5]. Sharma, N.R. (2008) "Educational and Vocational Guidance" B.P Printers, Agra.

[6]. Sharma, R.A. (1984-85) "Fundamentals of Education Research" International Publishing House, Delhi.

\section{Webliography}

[7]. http://www.dissertation.com

[8]. http://www.educationalthesis.com

[9]. http://www.occupationalaspiration.com 